\title{
TANGGAP KARAKTER MORFOFISIOLOGI JAGUNG TERHADAP KOMPOS LIMBAH JAGUNG DAN NPK DI TANAH ULTISOL
}

\author{
Yohanes Wahyudi'), Iwan Sasli2), Radian²) \\ 1) Program Magister Agroteknologi, Fakultas Pertanian, Universitas Tanjungpura \\ 2) Dosen Program Studi Agroteknologi, Fakultas Pertanian Universitas Tanjungpura \\ J. Prof. Dr. H. Hadari Nawawi Pontianak 78124, Indonesia \\ Korespondensi : johnwahyudi76@gmail.com
}

\begin{abstract}
Maize (Zea mays L.) is a very sensitive crop plant towards fertilization. Sufficient macro and micronutrients in the soil must be available during the maizes growth phase. Providing nutrients for maizes can be done by adding organic or inorganic fertilizers. The aim of this research is to determine the effects of interactions from maize waste composts and NPK fertilizers on the morphophysiological characters of maizes in ultisol soil. The research method used was a Randomized Block Design (RBD) with 2 factorials, the dose of maize waste composts $(K)$ and the dose of NPK fertilizers $(P)$. The result showed that the factor $K$ treatment is significantly affected the growth and the yield components of maizes. The level $k 2$ treatment (20 tons ha-1 of maize waste composts) generally gave the highest mean for maize cobs length and diameter, seeds per maize cob and per plot.
\end{abstract}

Key Words: yield, maize, compost, morphophysiology, ultisol.

\section{PENDAHULUAN}

Kalimantan Barat memiliki 244,985 hektar lahan yang potensial untuk pengembangan jagung. Berdasarkan data pada tahun 2018, produktivitas jagung di Kalimantan Barat sebesar 3.76 ton/ha, lebih rendah dibandingkan dengan produktivitas nasional yaitu 5.24 ton/ha (Badan Pusat Statistik, 2018). Upaya peningkatan produksi dapat dilakukan melalui penambahan areal luas tanam dan perbaikan sistem budidaya. Dalam perbaikan sistem budidaya, salah satu cara yang dapat dilakukan adalah penggunaan kombinasi pupuk organik dan anorganik untuk memberikan hasil yang maksimal.

Budidaya Tanaman jagung di Kalimantan Barat didominasi oleh lahan kering. Salah satu jenis tanah di lahan kering Kalimantan Barat adalah ultisol. Karakteristik dari tanah ultsiol, memiliki kemasaman tanah dan kandungan bahan organik yang rendah. Salah satu upaya perbaikan yang dapat dilakukan yaitu dengan memanfaatkan limbah tanaman yang dibuat sebagai kompos. 
Penambahan bahan organik berupa kompos sangat membantu dalam memperbaiki tanah yang terdegradasi karena dapat membantu penyediaan unsur hara tanah serta mengikat unsur hara yang mudah hilang sehingga efisiensi pemupukan menjadi lebih tinggi. Sumber bahan organik potensial yang dapat digunakan untuk membuat kompos dalam proses pemulihan dan pengelolaan lahan adalah limbah tanaman jagung yang ketersediaanya cukup melimpah di areal pertanaman jagung.

\section{METODE PENELITIAN}

Penelitian ini dilakukan di Desa Lembang Kecamatan Sanggau Ledo Kabupaten Bengkayang. Waktu Penelitian dilaksanakan mulai bulan Maret 2020 sampai dengan Juni 2020.

Penelitian ini menggunakan metode eksperimen lapangan dengan pola Rancangan Acak Kelompok (RAK) Faktorial yang terdiri atas 2 faktor. Faktor pertama yaitu dosis kompos limbah jagung $(\mathrm{K})$ dan faktor kedua yaitu dosis pupuk NPK (P). Faktor pertama: dosis kompos limbah jagung $(\mathrm{K})$, terdiri 4 taraf yaitu $\mathrm{KO}=$ pupuk kandang ayam $5 \mathrm{~kg} /$ petak (setara 10 ton/ha), $\mathrm{K} 1=\mathrm{kompos}$ limbah jagung $5 \mathrm{~kg} /$ petak (setara 10 ton/ha), K2 = kompos limbah jagung 10 $\mathrm{kg} /$ petak (setara 20 ton/ha), dan K3 = kompos limbah jagung $15 \mathrm{~kg} /$ petak (setara 30 ton/ha). Faktor Kedua: dosis pupuk NPK (P), terdiri dari 3 taraf, yaitu P1 = pupuk NPK $100 \mathrm{~g} /$ petak (setara $200 \mathrm{~kg} /$ ha NPK), P2 = pupuk NPK $150 \mathrm{~g} /$ petak (setara $300 \mathrm{~kg} /$ ha NPK), dan P3 = pupuk NPK $200 \mathrm{~g} /$ petak (setara $400 \mathrm{~kg} / \mathrm{ha}$ NPK. Secara keseluruhan terdapat 12 kombinasi perlakuan yaitu k0p1, k0p2, k0p3, $\mathrm{k} 1 \mathrm{p} 1, \mathrm{k} 1 \mathrm{p} 2, \mathrm{k} 1 \mathrm{p} 3, \mathrm{k} 2 \mathrm{p} 1, \mathrm{k} 2 \mathrm{p} 2, \mathrm{k} 2 \mathrm{p} 3, \mathrm{k} 3 \mathrm{p} 1, \mathrm{k} 3 \mathrm{p} 2, \mathrm{k} 3 \mathrm{p} 3$. Setiap perlakuan diulang sebanyak 3 kali, sehingga terdapat 36 petak perlakuan. Pada semua perlakuan diberikan juga pupuk Urea sesuai standar budidaya jagung yaitu 112,5 g/petak (setara $225 \mathrm{~kg} / \mathrm{ha}$ ). Dosis pemupukan didasarkan pada rekomendasi pemupukan jagung di lahan kering Kabupaten Bengkayang (BPTP Kalimantan Barat, 2019). Varietas jagung yang digunakan dalam penelitian ini adalah NK Perkasa

Pengamatan pertumbuhan meliputi tinggi tanaman, jumlah daun, bobot kering tanaman, laju pertumbuhan tanaman, indeks luas daun, laju asimilasi bersih dan berat kering akar. Pengamatan hasil meliputi panjang tongkol, 
diameter tongkol, bobot biji per tongkol, bobot biji per petak dan jumlah baris per tongkol.

Data hasil pengamatan dianalisis menggunakan uji $\mathrm{F}$ pada taraf nyata $5 \%$, bila hasil analisis terdapat pengaruh perbedaan yang nyata diantara perlakuan, maka dilakukan uji lanjut dengan BNT $5 \%$ untuk mengetahui perbedaan pada masing-masing perlakuan.

\section{HASIL DAN PEMBAHASAN}

\section{A. Hasil}

Berdasarkan analisis sidik ragam diketahui bahwa, interaksi antara perlakuan faktor dosis kompos limbah jagung $(\mathrm{K})$ dan faktor dosis pupuk NPK (P) berpengaruh tidak nyata terhadap semua variabel pertumbuhan dan hasil tanaman jagung NK Perkasa. Secara tunggal, perlakuan faktor K dan perlakuan foktor $\mathrm{P}$ memberi pengaruh nyata terhadap variabel pertumbuhan dan hasil tanaman jagung.

\section{Tinggi Tanaman $(\mathrm{cm})$}

Pengamatan terhadap parameter tinggi tanaman jagung dilakukan sebanyak 5 kali, yaitu pada Umur 14, 21, 28, 35 dan 45 hari setelah tanam (HST). Hasil Uji lanjut pengaruh perlakuan faktor tunggal dosis kompos limbah jagung (K) terhadap tinggi tanaman jagung, disajikan pada Tabel 1.

Tabel 1. Hasil Uji BNT Pengaruh Perlakuan Faktor Dosis Kompos Limbah Jagung (K) Terhadap Tinggi Tanaman Jagung

\section{Rerata tinggi tanaman $(\mathrm{cm})$}

\begin{tabular}{cccccc}
\cline { 2 - 5 } Kompos & 14 HST & 21 HST & 28 HST & 35 HST & 42 HST \\
\hline $\mathrm{k} 0$ & $28,74 \mathrm{~b}$ & $57,47 \mathrm{c}$ & $88,31 \mathrm{~b}$ & $130,40 \mathrm{~b}$ & $188.08 \mathrm{~b}$ \\
$\mathrm{k} 1$ & $28,62 \mathrm{~b}$ & $52,17 \mathrm{~b}$ & $75,44 \mathrm{a}$ & $105,76 \mathrm{a}$ & $156,14 \mathrm{a}$ \\
$\mathrm{k} 2$ & $23,94 \mathrm{a}$ & $46,69 \mathrm{a}$ & $71,92 \mathrm{a}$ & $102,75 \mathrm{a}$ & $154,59 \mathrm{a}$ \\
$\mathrm{k} 3$ & $25,07 \mathrm{a}$ & $49,12 \mathrm{ab}$ & $72,53 \mathrm{a}$ & $102,42 \mathrm{a}$ & $152,93 \mathrm{a}$ \\
\hline BNT $5 \%$ & 3,17 & 4,48 & 6,98 & 8,62 & 11,00
\end{tabular}

Keterangan : Angka yang diikuti oleh huruf yang sama berbeda tidak nyata pada uji BNT 5\% 
Tabel 1 menunjukkan secara umum bahwa taraf perlakuan k0 (pupuk kandang ayam 10 ton/ha) memberikan rerata tinggi tanaman terbaik dibandingkan taraf perlakuan k1 (kompos limbah jagung 10 ton/ha), k2 (kompos limbah jagung 20 ton/ha) dan k3 (kompos limbah jagung 30 ton/ha) pada umur 21, 28, 35, dan 42 HST. Pada umur 14 HST, taraf perlakuan k0 dan k1 memberikan rerata tinggi tanaman terbaik dan berbeda secara nyata dibandingkan taraf perlakuan $\mathrm{k} 2$ dan $\mathrm{k} 3$.

\section{Jumlah Daun (helai)}

Hasil Uji lanjut pengaruh perlakuan faktor tunggal dosis kompos limbah jagung (K) terhadap jumlah daun (helai), disajikan pada Tabel 2.

Tabel 2. Hasil Uji BNT Pengaruh Perlakuan Faktor Dosis Kompos Limbah Jagung (K) Terhadap Jumlah Daun Tanaman Jagung

Rerata jumlah daun (helai)

\begin{tabular}{cccccc}
\cline { 2 - 5 } Kompos & 14 HST & 21 HST & 28 HST & 35 HST & 42 HST \\
\hline $\mathrm{k} 0$ & $5,00 \mathrm{~b}$ & $6,30 \mathrm{~b}$ & $7,59 \mathrm{~b}$ & $9,48 \mathrm{~b}$ & $11,30 \mathrm{~b}$ \\
$\mathrm{k} 1$ & $4,81 \mathrm{a}$ & $5,37 \mathrm{a}$ & $6,63 \mathrm{a}$ & $8,15 \mathrm{ab}$ & $9,81 \mathrm{a}$ \\
$\mathrm{k} 2$ & $4,78 \mathrm{a}$ & $5,41 \mathrm{a}$ & $6,56 \mathrm{a}$ & $7,81 \mathrm{a}$ & $9,59 \mathrm{a}$ \\
$\mathrm{k} 3$ & $4,78 \mathrm{a}$ & $5,30 \mathrm{a}$ & $6,48 \mathrm{a}$ & $7,48 \mathrm{a}$ & $9,52 \mathrm{a}$ \\
\hline BNT $5 \%$ & 0,16 & 0,50 & 0,59 & 0,63 & 0,68
\end{tabular}

Keterangan : Angka yang diikuti oleh huruf yang sama berbeda tidak nyata pada uji BNT 5\%

Tabel 2 menunjukkan bahwa pada umur tanaman 14, 21, 28 dan 42 HST, taraf perlakuan k0 (pupuk kandang ayam 10 ton/ha) memberikan rerata jumlah daun terbaik dan berbeda nyata dibandingkan taraf perlakuan k1 (kompos limbah jagung 10 ton/ha), k2 (kompos limbah jagung 20 ton/ha) dan k3 (kompos limbah jagung 30 ton/ha). Pada umur 35 HST, taraf perlakuan k0 dan k1 memberikan jumlah daun terbaik dibandingkan taraf perlakuan k2 dan k3.

\section{Bobot Kering Tanaman (g)}

Hasil Uji lanjut pengaruh perlakuan faktor dosis kompos limbah jagung (K) terhadap bobot kering tanaman (g), disajikan pada Tabel 3. 
Tabel 3. Hasil Uji BNT Pengaruh Perlakuan Faktor Dosis Kompos Limbah Jagung (K) Terhadap Bobot Kering Tanaman Jagung

Rerata bobot kering tanaman (g)

\begin{tabular}{cccc} 
Kompos & 21 HST & 28 HST & 35 HST \\
\cline { 2 - 4 } $\mathrm{k} 0$ & $2,04 \mathrm{~b}$ & $5,90 \mathrm{~b}$ & $22,67 \mathrm{~b}$ \\
$\mathrm{k} 1$ & $1,18 \mathrm{a}$ & $3,08 \mathrm{a}$ & $11,80 \mathrm{a}$ \\
$\mathrm{k} 2$ & $1,07 \mathrm{a}$ & $3,45 \mathrm{a}$ & $6,74 \mathrm{a}$ \\
$\mathrm{k} 3$ & $1,26 \mathrm{a}$ & $2,26 \mathrm{a}$ & $6,49 \mathrm{a}$ \\
\hline BNT 5\% & 0,39 & 1,50 & 6,32
\end{tabular}

Keterangan : Angka yang diikuti oleh huruf yang sama berbeda tidak nyata pada uji BNT 5\%

Tabel 3 menunjukkan bahwa pada umur 21, 28 dan 35 HST, taraf perlakuan k0 (pupuk kandang ayam 10 ton/ha) memberikan bobot kering tanaman terbaik dan berbeda nyata dibandingkan taraf perlakuan k1 (kompos limbah jagung 10 ton/ha), k2 (kompos limbah jagung 20 ton/ha) dan k3 (kompos limbah jagung 30 ton/ha).

\section{Laju Pertumbuhan Tanaman $\left(\mathrm{g} / \mathrm{cm}^{2} /\right.$ hari)}

Hasil Uji lanjut pengaruh masing-masing perlakuan faktor tunggal dosis kompos limbah jagung $(\mathrm{K})$ dan dosis pupuk NPK $(\mathrm{P})$ terhadap laju pertumbuhan tanaman jagung (g/ $\mathrm{cm}^{2} /$ hari), disajikan pada Tabel 4 dan 5 .

Tabel 4. Hasil Uji BNT Pengaruh Perlakuan Faktor Dosis Kompos Limbah Jagung (K) Terhadap Laju Pertumbuhan Tanaman Jagung

\begin{tabular}{|c|c|c|c|}
\hline \multirow{2}{*}{ Kompos } & \multicolumn{3}{|c|}{ Rerata laju pertumbuhan tanaman jagung $\left(\mathrm{g} / \mathrm{cm}^{2} / \mathrm{hari}\right)$} \\
\hline & 21 HST & 28 HST & 35 HST \\
\hline $\mathrm{k} 0$ & $0,0001568 b$ & $0,0003948 b$ & $0,0017111 b$ \\
\hline $\mathrm{k} 1$ & $0,0000810 a$ & $0,0001934 a$ & $0,0009100 a$ \\
\hline $\mathrm{k} 2$ & $0,0000688 \mathrm{a}$ & $0,0002433 a$ & $0,0003454 a$ \\
\hline $\mathrm{k} 3$ & $0,0000845 a$ & $0,0001112 \mathrm{a}$ & $0,0004409 a$ \\
\hline BNT 5\% & 0,0000405 & 0,0003655 & 0,0006038 \\
\hline
\end{tabular}

Keterangan : Angka yang diikuti oleh huruf yang sama berbeda tidak nyata pada uji BNT 5\%.

Tabel 4 menunjukkan bahwa taraf perlakuan k0 (pupuk kandang ayam 10 ton/ha) memberikan laju pertumbuhan tanaman terbaik pada umur 21, 28, 
dan 35 HST dan berbeda nyata dibandingkan dengan taraf perlakuan k1 (kompos limbah jagung 10 ton/ha), k2 (kompos limbah jagung 20 ton/ha) dan k3 (kompos limbah jagung 30 ton/ha). Ketiga taraf perlakuan k1, k2, dan k3 sama-sama berbeda tidak nyata untuk laju pertumbuhan tanaman.

Tabel 5. Hasil Uji BNT Pengaruh Perlakuan Faktor Dosis Pupuk NPK (P) Terhadap Laju Pertumbuhan Tanaman Jagung Umur 28 HST

\begin{tabular}{cc}
\hline Pupuk NPK & Rerata laju pertumbuhan tanaman $\left(\mathrm{g} / \mathrm{cm}^{2} /\right.$ hari) \\
\hline p1 & $0,0003233 \mathrm{~b}$ \\
p2 & $0,0002332 \mathrm{ab}$ \\
p3 & $0,0001505 \mathrm{a}$ \\
\hline
\end{tabular}

BNT 5\% 0,0000032

Keterangan: Angka yang diikuti oleh huruf yang sama berbeda tidak nyata pada BNT 5\%

Tabel 5 menunjukkan bahwa taraf perlakuan p1 (pupuk NPK $200 \mathrm{~kg} / \mathrm{ha}$ ) memberikan laju pertumbuhan tanaman terbaik, diikuti taraf perlakuan p2 (pupuk NPK 300 kg/ha) dan p3 (pupuk NPK 400 kg/ha).

\section{Indeks Luas Daun $\left(\mathrm{cm}^{2}\right)$}

Hasil Uji lanjut pengaruh perlakuan faktor tunggal dosis kompos limbah jagung $(\mathrm{K})$ terhadap indeks luas daun, disajikan pada Tabel 6.

Tabel 6. Hasil Uji BNT Pengaruh Perlakuan Faktor Dosis Kompos Limbah Jagung (K) Terhadap Indeks Luas Daun Tanaman Jagung

\begin{tabular}{cccccc}
\hline \multirow{2}{*}{ Kompos } & \multicolumn{5}{c}{ Rerata indeks luas daun $\left(\mathbf{c m}^{2}\right)$} \\
\cline { 2 - 6 } & 14 HST & 21 HST & 28 HST & 35 HST & 42 HST \\
\hline $\mathrm{k} 0$ & $0,072 \mathrm{c}$ & $0,239 \mathrm{~b}$ & $0,563 \mathrm{~b}$ & $1,685 \mathrm{~b}$ & $3,179 \mathrm{~b}$ \\
$\mathrm{k} 1$ & $0,059 \mathrm{~b}$ & $0,133 \mathrm{a}$ & $0,357 \mathrm{a}$ & $0,951 \mathrm{a}$ & $2,062 \mathrm{a}$ \\
$\mathrm{k} 2$ & $0,049 \mathrm{a}$ & $0,116 \mathrm{a}$ & $0,375 \mathrm{a}$ & $0,632 \mathrm{a}$ & $2,208 \mathrm{a}$ \\
$\mathrm{k} 3$ & $0,053 \mathrm{a}$ & $0,129 \mathrm{a}$ & $0,262 \mathrm{a}$ & $0,795 \mathrm{a}$ & $2,320 \mathrm{a}$ \\
\hline BNT 5\% & 0,015 & 0,050 & 0,123 & 0,460 & 0,728
\end{tabular}

Keterangan: Angka yang diikuti oleh huruf yang sama berbeda tidak nyata pada BNT 5\%

Tabel 6 menunjukkan bahwa taraf perlakuan k0 (pupuk kandang ayam 10 ton/ha) memberikan indeks luas daun terbaik pada umur 14, 21, 28, 35, 42 HST 
dan berbeda nyata dibanding taraf perlakuan k1 (kompos limbah jagung 10 ton/ha), k2 (kompos limbah jagung 20 ton/ha) dan k3 (kompos limbah jagung 30 ton/ha).

\section{Laju Asimilasi Bersih (g/ $\mathrm{cm}^{2} /$ hari)}

Hasil Uji lanjut pengaruh masing-masing perlakuan faktor tunggal dosis kompos limbah jagung (K) dan dosis pupuk NPK (P) terhadap laju asimilasi bersih, disajikan pada Tabel 7 dan 8.

Tabel 7. Hasil Uji BNT Pengaruh Perlakuan Faktor Dosis Kompos Limbah Jagung (K) Terhadap Laju Asimilasi Bersih Tanaman Jagung

\begin{tabular}{ccc} 
& \multicolumn{2}{c}{ Rerata laju asimilasi bersih $\mathbf{~ ( g / \mathbf { c m } ^ { 2 } / \mathbf { h a r i } )}$} \\
\cline { 2 - 3 } Kompos & $\mathbf{2 8 ~ H S T}$ & $\mathbf{3 5 ~ H S T}$ \\
\hline $\mathrm{k} 0$ & $0,00099 \mathrm{ab}$ & $0,00156 \mathrm{c}$ \\
$\mathrm{k} 1$ & $0,00089 \mathrm{ab}$ & $0,00135 \mathrm{bc}$ \\
$\mathrm{k} 2$ & $0,00111 \mathrm{~b}$ & $0,00069 \mathrm{a}$ \\
$\mathrm{k} 3$ & $0,00060 \mathrm{a}$ & $0,00089 \mathrm{ab}$ \\
\hline BNT 5\% & 0,00040 & 0,00062
\end{tabular}

Keterangan: Angka yang diikuti oleh huruf yang sama berbeda tidak nyata pada BNT 5\%.

Tabel 7 menunjukkan bahwa pada umur 28 HST, laju asimilasi bersih tertinggi diperoleh dari taraf perlakuan k2 (kompos limbah jagung 20 ton/ha) meskipun tidak berbeda nyata dengan taraf perlakuan $\mathrm{kO}$ (pupuk kandang ayam 10 ton/ha) dan $\mathrm{k} 1$ (kompos limbah jagung 10 ton/ha). Laju asimilasi bersih terendah diperoleh dari taraf perlakuan k3 (kompos limbah jagung 30 ton/ha) dan berbeda nyata dibandingkan perlakuan $\mathrm{k} 2$, tetapi berbeda tidak nyata dibandingkan taraf perlakuan k0 dan k1. Pada umur 35 HST, taraf perlakuan $\mathrm{k} 0$ dan $\mathrm{k} 1$ memberikan laju asimilasi bersih terbaik dibandingkan perlakuan k2 dan $\mathrm{k} 3$. 
Tabel 8. Hasil Uji BNT Pengaruh Perlakuan Faktor Dosis Pupuk NPK (P) Terhadap Laju Asimilasi Bersih Tanaman Jagung Umur 28 HST

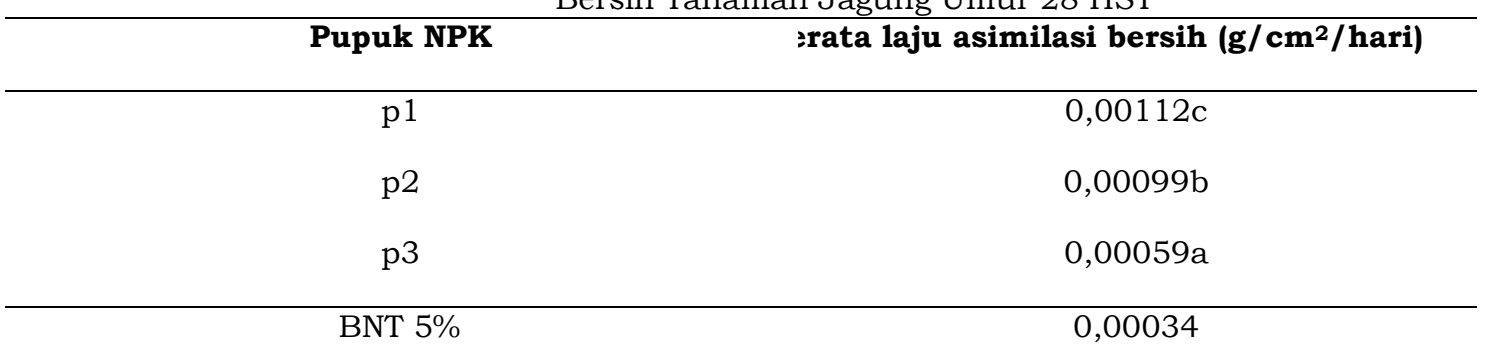

Keterangan: Angka yang diikuti oleh huruf yang sama berbeda tidak nyata pada BNT 5\%

Tabel 8 menunjukkan bahwa taraf perlakuan p1 (pupuk NPK $200 \mathrm{~kg} / \mathrm{ha}$ ) memberikan laju asimilasi bersih terbaik, diikuti pelakuan p2 (pupuk NPK 300 $\mathrm{kg} / \mathrm{ha}$ ) dan perlakuan p3 (pupuk NPK $400 \mathrm{~kg} / \mathrm{ha}$ ). Masing-masing taraf perlakuan berbeda nyata terhadap satu sama lain.

\section{Berat Kering Akar (g)}

Hasil analisis sidik ragam menunjukkan bahwa perlakuan faktor dosis kompos limbah jagung (K) secara tunggal, perlakuan faktor P secara tunggal, dan interaksi keduanya memberikan pengaruh tidak nyata terhadap berat kering akar umur 42 HST.

\section{Panjang Tongkol $(\mathrm{cm})$}

Hasil Uji lanjut pengaruh perlakuan factor tunggal dosis kompos limbah jagung $(\mathrm{K})$ terhadap panjang tongkol $(\mathrm{cm})$, disajikan pada Tabel 9.

Tabel 9. Hasil Uji BNT Pengaruh Perlakuan Faktor Dosis Kompos Limbah Jagung (K) Terhadap

\begin{tabular}{cc} 
Kompos & Panjang Tongkol \\
\hline $\mathrm{k} 0$ & Rerata panjang tongkol (cm) \\
$\mathrm{k} 1$ & $15,34 \mathrm{ab}$ \\
$\mathrm{k} 2$ & $15,73 \mathrm{~b}$ \\
$\mathrm{k} 3$ & $15,57 \mathrm{~b}$ \\
\hline BNT 5\% & $15,12 \mathrm{a}$ \\
\hline
\end{tabular}

Keterangan : Angka yang diikuti oleh huruf yang sama berbeda tidak nyata pada BNT 5\%

Tabel 9 menunjukkan bahwa rerata panjang tongkol tertinggi diperoleh dari taraf perlakuan k1 (kompos limbah jagung 10 ton/ha) yaitu sebesar 15,73 
$\mathrm{cm}$, meskipun tidak berbeda nyata dibandingkan taraf perlakuan k2 (kompos limbah jagung 20 ton/ha) dan k0 (pupuk kandang ayam 10 ton/ha). Panjang tongkol terendah diperoleh dari taraf perlakuan k3 (kompos limbah jagung 30 ton/ha).

\section{Diameter Tongkol (cm)}

Hasil Uji lanjut pengaruh perlakuan factor tunggal dosis kompos limbah jagung $(\mathrm{K})$ terhadap diameter tongkol $(\mathrm{cm})$, disajikan pada Tabel 10.

Tabel 10. Hasil Uji BNT Pengaruh Perlakuan Faktor Dosis Kompos Limbah Jagung (K) Terhadap

\begin{tabular}{cc} 
Kompos & Diameter Tongkol \\
\hline $\mathrm{k} 0$ & Rerata diameter tongkol (cm) \\
$\mathrm{k} 1$ & $4,31 \mathrm{a}$ \\
$\mathrm{k} 2$ & $4,38 \mathrm{ab}$ \\
$\mathrm{k} 3$ & $4,43 \mathrm{~b}$ \\
\hline BNT $5 \%$ & $4,37 \mathrm{ab}$ \\
\hline
\end{tabular}

Keterangan : Angka yang diikuti oleh huruf yang sama berbeda tidak nyata pada BNT 5\%

Tabel 10 menunjukkan bahwa rerata diameter tongkol tertinggi diperoleh dari taraf perlakuan k2 (kompos limbah jagung 20 ton/ha) yaitu 4,43 cm, meskipun tidak berbeda nyata dibandingkan taraf perlakuan k1 (kompos limbah jagung 10 ton/ha) dan k3 (kompos limbah jagung 30 ton/ha). Diameter tongkol terendah diperoleh dari taraf perlakuan k0 (pupuk kandang ayam 10 ton/ha) yaitu sebesar $4,31 \mathrm{~cm}$.

\section{Bobot Biji Per Tongkol (g)}

Hasil Uji lanjut pengaruh perlakuan factor tunggal dosis kompos limbah jagung (K) terhadap bobot biji kering per tongol (g), disajikan pada Tabel 11 . 
Tabel 11. Hasil Uji BNT Pengaruh Perlakuan Faktor Dosis Kompos Limbah Jagung (K) Terhadap Bobot Biji Per Tongkol

\begin{tabular}{cc}
\hline Kompos & Rerata bobot biji per tongkol (g) \\
\hline $\mathrm{k} 0$ & $141,99 \mathrm{ab}$ \\
$\mathrm{k} 1$ & $146,43 \mathrm{bc}$ \\
$\mathrm{k} 2$ & $150,13 \mathrm{c}$ \\
$\mathrm{k} 3$ & $138,47 \mathrm{a}$ \\
\hline BNT $5 \%$ & 6,92
\end{tabular}

Keterangan : Angka yang diikuti oleh huruf yang sama berbeda tidak nyata pada BNT 5\%

Tabel 11 menunjukkan bahwa rerata bobot biji per tongkol tertinggi diperoleh dari taraf perlakuan k2 (kompos limbah jagung 20 ton/ha) yaitu 150,13 g, meskipun tidak berbeda nyata dibandingkan taraf perlakuan $\mathrm{k} 1$ (kompos limbah jagung 10 ton/ha) dengan rerata 146,4 g. Bobot biji per tongkol terendah diperoleh dari taraf perlakuan k3 (kompos limbah jagung 30 ton/ha) yaitu $138,47 \mathrm{~g}$.

\section{Bobot Biji Per Petak (g)}

Hasil Uji lanjut pengaruh perlakuan factor tunggal dosis kompos limbah jagung (K) terhadap bobot biji kering per petak (g), disajikan pada Tabel 12.

Tabel 12. Hasil Uji BNT Pengaruh Perlakuan Faktor Dosis Kompos Limbah Jagung (K) Terhadap

\begin{tabular}{cc} 
& Bobot Biji Per Petak \\
\hline Kompos & Rerata bobot biji per petak (g) \\
\hline k0 1 & $1334,67 \mathrm{~b}$ \\
k2 & $1329,11 \mathrm{~b}$ \\
k3 & $1386,00 \mathrm{~b}$ \\
\hline BNT $5 \%$ & $1251,22 \mathrm{a}$ \\
\hline
\end{tabular}

Keterangan: Angka yang diikuti oleh huruf yang sama berbeda tidak nyata pada BNT 5\%

Tabel 12 menunjukkan bahwa rerata bobot biji per petak tertinggi diperoleh dari taraf perlakuan k2 (kompos limbah jagung 20 ton/ha) yaitu $1386 \mathrm{~g}$, meskipun tidak berbeda nyata dengan perlakuan k0 (pupuk kandang ayam 10 ton/ha) dan k1 (kompos limbah jagung 10 ton/ha) yang masing-masing 
memberikan nilai rerata 1334,67 g dan 1329,11 g. Bobot biji per petak terendah diperoleh dari taraf perlakuan k3 (kompos limbah jagung 30 ton/ha) yaitu $1251,22 \mathrm{~g}$.

\section{Jumlah Baris Biji Per Tongkol (baris/tongkol)}

Hasil Uji lanjut pengaruh perlakuan factor tunggal dosis pupuk NPK (P) terhadap jumlah baris biji per tongkol, disajikan pada Tabel 13.

Tabel 13. Hasil Uji BNT Pengaruh Perlakuan Faktor Dosis Pupuk NPK (P) Terhadap Jumlah Baris Biji Per Tongkol

\begin{tabular}{cc} 
Pupuk NPK (B) & Rerata baris biji per tongkol \\
\hline p1 & $16,35 \mathrm{~b}$ \\
p2 & $16,26 \mathrm{~b}$ \\
p3 & $15,99 \mathrm{a}$ \\
\hline BNT 5\% & 0,25
\end{tabular}

Keterangan: Angka yang diikuti oleh huruf yang sama berbeda tidak nyata pada BNT 5\%

Tabel 13 menunjukkan bahwa rerata baris biji per tongkol tertinggi diperoleh dari taraf perlakuan p1 (pupuk NPK $200 \mathrm{~kg} / \mathrm{ha}$ ) yaitu 16,35 baris/tongkol, meskipun tidak berbeda nyata dengan perlakuan p2 (pupuk NPK $300 \mathrm{~kg} / \mathrm{ha}$ ) yaitu 16,26 baris/tongkol. Jumlah baris biji per tongkol terendah diperoleh dari perlakuan p3 (pupuk NPK $400 \mathrm{~kg} / \mathrm{ha}$ ) yaitu 15,99 baris/tongkol.

\section{B. Pembahasan}

Pengaruh nyata dari faktor dosis kompos limbah jagung (K) terhadap pertumbuhan dan hasil tanaman jagung berkaitan erat dengan penyediaan bahan organik yang diperlukan untuk memperbaiki sifat fisik, kimia dan biologi tanah. Haryadi et al. (2015) mengatakan bahwa pemberian pupuk organik dapat menjaga agroekosistem terutama mencegah terjadinya degradasi lahan dan dapat memperbaiki kesuburan tanah sehingga dapat menunjang pertumbuhan dan perkembangan tanaman. Meskipun demikian, menurut Sutanto (2002) kandungan hara makro berupa N, P dan K yang terdapat pada pupuk organik tergolong rendah dan ketersediaan unsur hara lebih lambat dibandingkan pupuk anorganik sehingga dalam aplikasi diperlukan dalam jumlah yang banyak. 
Menurut Ogbonna et al (2012) bahwa aplikasi kompos limbah organik ke lahan pertanaman jagung pada tanah Ultisol memperbaiki sifat fisik tanah, meningkatkan kandungan hara $\mathrm{N}, \mathrm{P}$, dan $\mathrm{K}$, serta beberapa hara mikro seperti: $\mathrm{Zn}, \mathrm{Fe}$, dan $\mathrm{Cu}$.

Pertumbuhan vegetatif adalah pertambahan volume, jumlah, bentuk dan ukuran organ-organ vegetatif tanaman yang terjadi pada daun, batang dan akar. Pada masa pertumbuhan vegetatif, masing-masing dosis perlakuan faktor $\mathrm{K}$ memberikan pengaruh yang berbeda antara satu sama lain terhadap karakter morfofisiologi tanaman jagung. Pengaruh nyata faktor $\mathrm{K}$ terhadap variabel pertumbuhan meliputi tinggi tanaman, jumlah daun, bobot kering tanaman, laju pertumbuhan tanaman, indeks luas daun dan laju asimilasi bersih, namun berpengaruh tidak nyata terhadap berat kering akar.

Pengaruh nyata dari perlakuan faktor $\mathrm{K}$ terhadap variabel pertumbuhan vegetatif menunjukkan bahwa pada taraf perlakuan k0 (pupuk kandang ayam 10 ton/ha) secara umum memberikan hasil terbaik. Hal ini diduga karena berdasarkan hasil uji laboratorium menunjukkan bahwa pupuk kandang ayam mengandung unsur hara N, P dan $\mathrm{K}$ yang cukup tinggi.

Menurut Hasibuan (2010) menambahkan nitrogen bermanfaat untuk pertumbuhan tanaman. Nitrogen yang ada dalam tanaman merangsang aktivitas meristematis. Nitrogen ini didapat dari cadangan $\mathrm{N}$ mineral yang ada pada masing-masing perlakuan dalam penelitian. Dengan semakin meningkatnya jumlah $\mathrm{N}$ yang diserap oleh tanaman, maka jaringan meristematik pada titik tumbuh batang semakin aktif. Menurut Setiawan (2009) menambahkan unsur hara $\mathrm{P}$ bagi tanaman lebih banyak berfungsi untuk merangsang pertumbuhan akar, khususnya akar tanaman muda. Fosfor juga berfungsi untuk membantu asimilasi dan pernafasan, sekaligus mempercepat pembungaan serta pemasakan biji dan buah. Dinyatakan oleh Smartagro (2009) bahwa menambahkan kalium merupakan pengaktif dari sejumlah besar enzim yang penting untuk proses fotosintesis dan respirasi. Kalium mengaktifkan juga enzim yang membentuk pati dan protein.

Pada variabel pengamatan hasil, pengaruh nyata dari perlakuan faktor $\mathrm{K}$ tampak pada diameter tongkol, bobot biji per tongkol dan bobot biji per petak. 
Hasil terbaik diperoleh dari perlakuan faktor dosis kompos limbah jagung $(\mathrm{K})$ pada taraf perlakuan k2 (kompos limbah jagung 20 ton/ha).

Kompos limbah jagung mempunyai kandungan hara $\mathrm{N}, \mathrm{P}$ dan $\mathrm{K}$ yang cukup tinggi dan diduga dengan taraf perlakuan 20 ton/ha dapat meningkatkan ketersediaan hara dalam tanah yang dapat digunakan untuk metabolisme tanaman. Fenomena ini dapat terjadi karena kompos dapat memperbaiki sifat fisik, kimia, dan biologi tanah untuk mendukung pertumbuhan tanaman menjadi lebih baik. Aplikasi kompos dapat mengurangi penggunaan pupuk kimia dan meningkatkan kesuburan tanah, daya menyimpan air, dan produktivitas tanaman bertahan dalam jangka panjang (Natsheh dan Mousa, 2014).

Perlakuan faktor P secara tunggal berpengaruh secara nyata terhadap laju pertumbuhan tanaman, laju asimilasi bersih, dan jumlah baris biji per tongkol. Menurut Gardner et al. (1991), laju pertumbuhan tanaman merupakan pertambahan bobot kering tanaman per satuan luas lahan yang ditempati tanaman dalam waktu tertentu. Semakin besar bobot kering tanaman maka laju pertumbuhan tanaman juga akan semakin meningkat.

Laju pertumbuhan tanaman terkait erat dengan indeks luas daun. Nilai indeks luas daun di atas optimum menyebabkan nilai laju pertumbuhan tanaman akan menurun seiring dengan meningkatnya luas daun. Luas daun yang meningkat akan menyebabkan terjadinya penaungan antar daun satu dengan yang lainnya. Penaungan ini mengakibatkan daun yang berada di bawah tidak melakukan fotosintesis secara optimum sehingga akan mempengaruhi dan menurunkan pertumbuhan tanaman (Gardner et al., 1991).

Laju asimilasi bersih merupakan laju penimbunan berat kering tanaman per satuan luas daun per satuan waktu atau ukuran rata-rata efisiensi fotosintesis daun dalam suatu tanaman budidaya (Gardner et al., 1991). Dengan demikian, laju pertumbuhan tanaman dan laju asimilasi bersih terakit erat dengan pertumbuhan vegetatif dari waktu ke waktu.

Perlakuan faktor P (dosis pupuk NPK) berperan dalam mempengaruhi pertumbuhan dan perkembangan tanaman di mana pupuk NPK dapat memperbaiki sifat kimia tanah karena mengandung unsur hara makro yang tinggi, lebih spesifik, ketersediaan hara cepat, dan lebih mudah diaplikasikan di lapangan sehingga lebih cepat diserap oleh tanaman. Namun perlu diperhatikan 
juga bahwa penggunaan pupuk NPK yang merupakan pupuk anorganik secara terus menerus menurunkan kesuburan fisik dan biologi tanah (Sutanto, 2002).

Aplikasi dosis pupuk NPK pada taraf $200 \mathrm{~kg} /$ ha memberikan laju asimilasi bersih terbaik. Dosis pupuk NPK pada taraf $200 \mathrm{~kg} / \mathrm{ha}$ dan $300 \mathrm{~kg} / \mathrm{ha}$ menunjukkan hasil terbaik untuk variabel laju pertumbuhan tanaman dan jumlah baris biji per tongkol yaitu 16 baris. Jumlah baris per tongkol tersebut sesuai dengan deskripsi jagung varietas NK Perkasa. Hasil tersebut menunjukkan bahwa jumlah baris per tongkol tidak dipengaruhi oleh peningkatan dosis pupuk NPK, tetapi lebih dipengaruhi oleh faktor genetis.

Dengan jarak tanam $70 \mathrm{~cm} \times 20 \mathrm{~cm}$, populasi jagung bisa mencapai 71.428 tanaman/ha. Dengan populasi tersebut taraf perlakuan k2 (kompos limbah jagung 20 ton/ha) memberikan potensi hasil terbaik yaitu 10,72 ton/ha.

\section{SIMPULAN}

Berdasarkan hasil penelitian dapat disimpulkan bahwa:

1. Interaksi antara faktor kompos limbah jagung $(K)$ dan faktor pupuk NPK (P) tidak memberi pengaruh nyata terhadap karakter morfofisiologi jagung di tanah ultisol.

2. Perlakuan faktor $\mathrm{K}$ secara tunggal berpengaruh nyata terhadap tinggi tanaman, jumlah daun, bobot kering tanaman, laju pertumbuhan tanaman, indeks luas daun, laju asimilasi bersih, panjang tongkol, diameter tongkol, bobot biji per tongkol, dan bobot biji per petak.

3. Perlakuan faktor P secara tunggal berpengaruh secara nyata terhadap laju pertumbuhan tanaman, laju asimilasi bersih, dan jumlah baris biji per tongkol.

4. Taraf perlakuan k0 (pupuk kandang ayam 10 ton/ha) secara umum memberikan rerata pertumbuhan terbaik.

5. Taraf perlakuan k2 (kompos limbah jagung 20 ton/ha) memberikan rerata hasil terbaik.

6. Taraf pelakuan p1 (pupuk NPK $200 \mathrm{~kg} / \mathrm{ha}$ ) memberikan rerata laju pertumbuhan tanaman dan laju asimilasi bersih terbaik pada umur 28 HST. 


\section{DAFTAR PUSTAKA}

Badan Pusat Statistik. 2018. Kalimantan Barat Dalam Angka. Badan Pusat Statistik Kalimantan Barat. Pontianak.

BPTP Kalimantan Barat, 2019. Rekomendasi Teknologi Budidaya Padi, Jagung Kedelai (PAJALE) Provinsi Kalimantan Barat. Balai Penelitian dan Pengembangan Penelitian. Kementerian Pertanian. 107 hal.

Gardner, F.P., R. B. Pearce dan R. L. Mitchell. 1991. Fisiologi Tanaman Budidaya. UI Press. Jakarta. 428 hal.

Haryadi, Dede et al. 2015. Pengaruh Pemberian Beberapa Jenis Pupuk Terhadap Pertumbuhan dan Produksi Tanaman Kailan (Brassica alboglabra L.). JOM Faperta Vol. 2, No. 2, Okt. 2015: 1-10.

Hasibuan, B.E. 2010. Pupuk dan Pemupukan. Fakultas Pertanian Universitas Sumatera Utara. Medan.

Natsheh, B. dan S. Mousa. 2014. Effect Organic and Inorganic Fertilizelizer On Soil and Cucumber (Cucumis sativa L.) Plant Productivity. International Jounal of Agriculture and Forestry Vol.4, No. 3, 2014: 166-170.

Ogbonna, D.N. et al. 2012. Effect Of Organic Waste Compost And Microbial Activity On The Growth Of Maize In The Ultisol In Port Harcourt. Nigeria. African Journal of Biotechnology Vol. 11, No. 62, August 2012: 12546-12554.

Setiawan, A. E. 2009. Memanfaatkan Kotoran Ternak. Penebar Swadaya. Jakarta.

Smartagro 2009. Manfaat Pupuk Kandang Ayam. http://smartagro2009.wordpress.com/manfaat-pupuk-kandang. 8 Juli 2020.

Sutanto, R. 2002. Penerapan Pertanian Organik. Kanisius. Yogyakarta. 